\title{
Elevated plasma insulin-like growth factor binding protein-1 levels in Type 1 (insulin-dependent) diabetic patients with peripheral neuropathy
}

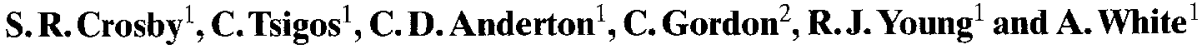 \\ ${ }^{1}$ Department of Medicine, University of Manchester, Hope Hospital, Salford and \\ ${ }^{2}$ Department of Clinical Endocrinology, Manchester Royal Infirmary, Manchester, UK
}

\begin{abstract}
Summary. Previous studies have suggested that nerve regeneration may be defective in patients with diabetic polyneuropathy. Since insulin-like growth factor I (IGF-I) has been shown to stimulate nerve regeneration, and IGF binding protein-1 is acutely regulated by plasma insulin we have investigated the relationships between plasma IGF-I, IGFBP-1, glucose and insulin in Type 1 (insulin-dependent) diabetic patients with peripheral polyneuropathy. Plasma samples were taken at hourly intervals over an 11-h period (08.00-19.00 hours) in order to characterise secretory profiles for 15 Type 1 diabetic patients (eight neuropathic and seven non-neuropathic) and eight non-diabetic control subjects. In the non-diabetic subjects, mean plasma IGF-I levels were stable throughout the 11 -h period with a range of $97 \mu \mathrm{g} / \mathrm{l}-169 \mu \mathrm{g} / \mathrm{l}$. In contrast, mean plasma IGFBP-1 levels declined steadily from a high level of $1.99 \mu \mathrm{g} / 1$ at 08.00 hours to approximately one half $(0.86 \mu \mathrm{g} / 1)$ at 15.00 hours. Comparison of areas under the curves revealed significant negative correlations between IGFBP-1 and glucose $(-0.88$, $p=0.01)$, IGFBP-1 and insulin $(-0.75, p=0.016)$, and IGFBP-1 and IGF-I $(-0.68, p=0.03)$. A significant positive correlation was found between insulin and IGF-I $(+0.89$,
\end{abstract}

$p=0.001)$. The diabetic patients had markedly elevated plasma IGFBP-1 levels (area under curve, $p=0.01$ ) and lower plasma IGF-I levels ( $p=0.033$ ) even though these patients were hyperinsulinaemic throughout the study period. The neuropathic diabetic patients had grossly elevated IGFBP-1 levels ( $\bar{x}=40 \mu \mathrm{g} / 1$ at 08.00 hours) which were significantly higher (area under curve, $p=0.05$ ) than in patients without neuropathy ( $\bar{x}=15 \mu \mathrm{g} / 1$ at 08.00 hours). However, plasma levels of insulin and IGF-I in neuropathic and non-neuropathic subjects were similar, suggesting that the regulation of IGFBP-1 is more resistant to insulin in the neuropathic patients. In contrast to the non-diabetic subjects comparison of area under curve values revealed no positive correlation between insulin and IGF-I or negative correlations between IGF-I and IGFBP-1, and IGFBP- 1 and glucose. We conclude that in Type 1 diabetes the relationships between plasma glucose, insulin, IGF-I and IGFBP-1 are clearly abnormal, and these abnormalities are more pronounced in patients with peripheral neuropathy.

Key words: Insulin-like growth factor binding protein-1, diabetes mellitus, peripheral neuropathy.
The pathogenesis of diabetic polyneuropathy is still poorly understood, although accumulating evidence suggests that the duration and severity of hyperglycaemia are important [1]. Tissue damage due to hyperglycaemia may be mediated by the consequences of polyol pathway activation and by non-enzymatic glycation [2]. While these may be important factors causing neuronal degeneration, they are probably not sufficient in themselves to explain the diversity of types and severities of clinical neuropathy and neuropathology. We have previously suggested [3], on the basis of histomorphometric studies of the sural nerve in patients with diabetic polyneuropathy, that regenerative activity is also defective. These observations imply that the effectiveness of nerve fibre regeneration may play a role in determining the outcome of the pathological process in peripheral neuropathy. Because growth factors are important regulators of tissue regeneration, it is conceiv- able that defective neuronal regeneration in peripheral neuropathy may be due to abnormalities in the activity of neurotrophic growth factors.

A number of studies suggest that insulin-like growth factor I (IGF-I) displays typical characteristics of a neurotrophic paracrine growth factor which is important for nerve regeneration. For example, studies in rats have shown that Schwann cells from peripheral nerves synthesize IGF-I and that the amount of IGF-I increases locally after a crush lesion [4]. Furthermore, in streptozotocin-diabetic rats with impaired nerve regeneration serum IGF-I levels are reduced and locally applied insulin stimulates regeneration in this model and restores serum IGF-I to normal [5].

IGF-I is influenced by metabolic status since IGF-I activity has been shown to be regulated by insulin and therefore indirectly by glucose [6]. The activity of IGF-I is also 
Table 1. Clinical characteristics of the subjects

\begin{tabular}{|c|c|c|c|}
\hline & \multirow[t]{2}{*}{ Control subjects } & \multicolumn{2}{|l|}{ Diabetic patients } \\
\hline & & No neuropathy & Neuropathy \\
\hline$\overline{\mathrm{n} \text { (male:female) }}$ & $5: 3$ & $6: 1$ & $5: 3$ \\
\hline $\mathrm{BMI}\left(\mathrm{kg} / \mathrm{m}^{2}\right)$ & $27(22-31)$ & $25(23-26)$ & $24(20-31)$ \\
\hline Duration of diabetes (years) & & $17(8-22)$ & $19(11-30)$ \\
\hline $\mathrm{HbA}_{1}(\%)$ & $(5.0-8.0)$ & $8.9(7.8-9.7)$ & $11(9.3-12.9)$ \\
\hline Painful: painless neuropathy & & - & $5: 3$ \\
\hline Vibration perception (V) & & $14.4(9-17)$ & $31.1(11-60)$ \\
\hline Maximal/minimum heart rate (beats/min) & & $17.6(8-29)$ & $3.6(0-12)$ \\
\hline Peroneal $\mathrm{MNCV}\left(\mathrm{m} \cdot \mathrm{s}^{-1}\right)$ & & $42(39-47)$ & $32(25-42)$ \\
\hline Sural SPA $(\mu V)$ & & $6.5(3-12)$ & $1.1(0-5)$ \\
\hline Insulin $(\mathrm{IU} / 24 \mathrm{~h})$ & & $54(42-64)$ & $60(38-100)$ \\
\hline
\end{tabular}

Values are means with ranges in parentheses. Peroneal MNCV, Peroneal motor nerve conduction velocity; Sural SPA, sural sensory potential amplitude

modulated in plasma and the tissues by a family of at least six IGF binding proteins (IGFBPs) [7]. IGFBP-1 has a molecular weight of approximately $25 \mathrm{kDa}$ [8], is negatively regulated by insulin $[9,10]$, and inhibits the activity of IGF-I in vitro [11]. It has been reported to be elevated in the plasma of poorly-controlled diabetic patients $[12,13]$, but to date there have been no studies investigating plasma IGFBP -1 in patients with a specific and wellcharacterised long-term complication of diabetes such as peripheral neuropathy.

The purpose of the present study was to investigate whether, in patients with diabetic neuropathy, there are abnormalities of IGF-I or IGFBP-1 which may contribute to impaired neuronal regeneration. We have examined the relationships between IGF-I, IGFBP-1, glucose and insulin over an 11 -h period in the plasma from neuropathic and non-neuropathic Type 1 diabetic patients and non-diabetic subjects.

\section{Subjects and methods}

Blood samples were taken via an indwelling catheter at hourly intervals over an 11 -h period (08.00-19.00 hours) from 15 patients with Type 1 diabetes (eight neuropathic and seven non-neuropathic) and eight non-diabetic control subjects. All subjects in the study followed a fixed feeding regimen (i. e. overnight fast and light meals at $07.00,12.00$ and 18.50 hours), and continued with their usual insulin therapy. Neuropathy was characterized as described previously [14] using a standard symptom questionnaire and clinical evaluation of peripheral nerves, quantitative sensory testing of vibration and temperature perception, four cardiovascular autonomic function tests and peripheral nerve electrophysiology of peroneal and sural nerves. Table 1 lists the characteristics of the normal control subjects and diabetic patients studied and some of the neuropathy parameters measured. Blood samples $(5 \mathrm{ml})$ were collected into lithium heparin tubes, centrifuged immediately and the plasma was frozen and stored at $-70^{\circ} \mathrm{C}$ prior to assay.

$I G F-I$ radioimmunoassay ( $R I A$ ). Plasma IGF-I was measured by RIA after acid-ethanol extraction according to the method of Daughaday et al. [15]. The antibody used in the assay was a monoclonal antibody (MAb I-5C9) which was generated after immunization of Balb/c mice with recombinant human IGF-I (rhIGF-I) conjugated tohuman serum $\alpha$-globulin (akind gift from Dr. C. A. Morrison, CibaGeigy, Basle, Switzerland). The assay diluent was $0.1 \mathrm{~mol} / \mathrm{l}$ sodium phosphate buffered saline $\mathrm{pH} 7.4$ containing $0.1 \%$ bovine serum al- bumin (Sigma Chemical Co., Poole, Dorset, UK). Briefly, ${ }^{125} \mathrm{I}$-labelled rhIGF-I $(20,000 \mathrm{cpm} / 200 \mu \mathrm{l})$ was incubated with anti-IGF-I monoclonal antibody (MAb I-5C9,200 $\mu \mathrm{l}$ ) and $40 \mu \mathrm{l}$ of extracted sample or standard for $16 \mathrm{~h}$ at $4^{\circ} \mathrm{C}$. Separation of bound and free radioligand was with anti-mouse immunoglobulin linked to cellulose (Sac-Cel, Immunodiagnostic systems, Washington, Tyne and Wear, $\mathrm{UK}$ ) for $1 \mathrm{~h}$ at $37^{\circ} \mathrm{C}$ followed by centrifugation at $600 \mathrm{~g}$ for $5 \mathrm{~min}$ at $4^{\circ} \mathrm{C}$. rhIGF-I (World Health Organisation) International reference reagent code $87 / 518$ from the National Institute for Biological Standards and Control (London, UK) was used to standardize the assay. The detection limit (defined as a $10 \%$ displacement of the binding at zero dose of IGF-I) was $40 \mathrm{ng} / \mathrm{ml}$. The coefficients of variation (CV) at $88 \mathrm{ng} / \mathrm{ml}, 250 \mathrm{ng} / \mathrm{ml}$, and $500 \mathrm{ng} / \mathrm{ml}$, were $25 \%, 11 \%$, and $8 \%$ respectively. Cross-reactivity with IGF-II and insulin was less than $1 \%$ for both peptides and IGF-I levels measured in dilutions of plasma from acromegalic patients gave values which were parallel to the standard curve. In view of the fact that IGF-I levels were to be measured in plasma which may contain high concentrations of IGFBP-1, the potential interference of IGFBP-1 on the IGF-I assay was investigated. IGF-I standards were diluted in human plasma containing $0,1,6,30$, and $160 \mu \mathrm{g} / \mathrm{l}$ of IGFBP- 1 and assayed after acidethanol extraction. Standard curves were superimposable (data not shown) showing that at these levels, IGFBP-1 does not interfere with the measurement of IGF-I using this RIA.

IGFBP-1 immunoenzymetric assay. Plasma IGFBP-1 was measured with a two-site immunoenzymetric assay (IEMA; Medix Biochemi$\mathrm{ca}$, Kaunianen, Finland). The assay used two MAbs, which recognize distinct epitopes on the IGFBP-1 molecule. One of the antibodies was immobilized on a microtitre plate and the other MAb was conjugated to horseradish peroxidase (HRP). Standardization of the assay was with human IGFBP-1 purified from amniotic fluid (lot 307/3235; Behring Institute, Marburg, FRG). The assay protocol involved incubating $20 \mu \mathrm{l}$ of standards, controls, and plasma samples with $80 \mu \mathrm{l}$ of assay diluent in the MAb-coated microtitre wells. After $30 \mathrm{~min}$ at room temperature, the wells were aspirated and washed three times with assay diluent $(300 \mu \mathrm{l})$. MAb-enzyme conjugate $(100 \mu \mathrm{l})$ was then added to each well and incubated for $30 \mathrm{~min}$ at room temperature. The plates were thoroughly washed as above and $100 \mu \mathrm{l}$ of the HRP-substrate solution was added. After 10 min the absorbance at $414 \mathrm{~nm}$ was measured. The minimum detection limit of the assay was $0.4 \mu \mathrm{g} /(2 \mathrm{SD}$ from the zero standard) and the working range was $0.4-160 \mu \mathrm{g} / \mathrm{l}(\mathrm{CV}<5 \%)$.

Glucose measurement. Plasma glucose was measured using a standard automated glucose oxidase technique.

Insulin RIA. Plasma insulin was measured by RIA as described previously [16]. Briefly, the assay employed a guinea-pig antiserum to human insulin (ICN/Flow Laboratories, Rickmansworth, Herts, UK), ${ }^{125}$ I-labelled insulin (Medgenix, High Wycombe, Bucks, UK) 


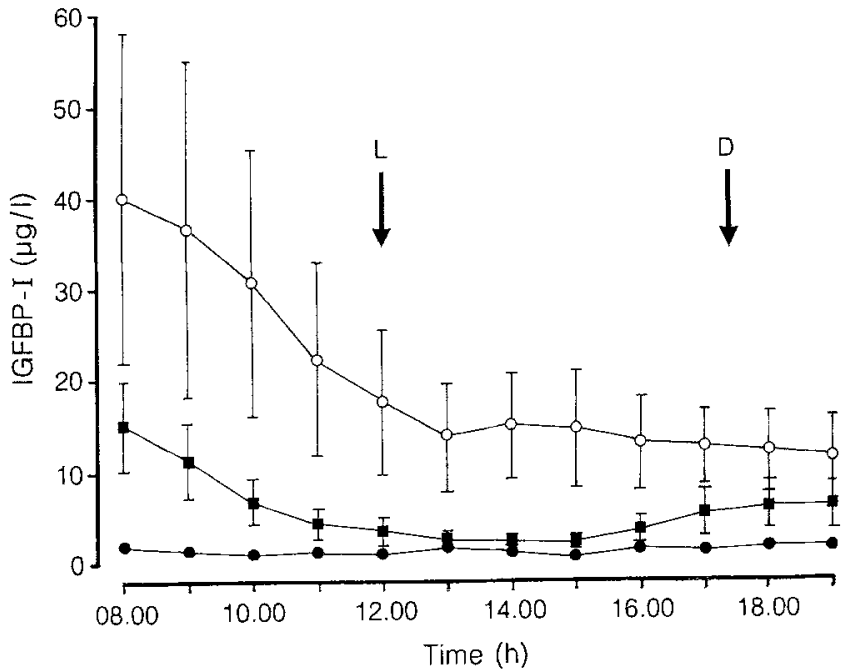

Fig. 1. Plasma insulin-like growth factor binding protein-1 (IGFBP1) concentrations measured over $11 \mathrm{~h}$ in non-diabetic subjects $(\bullet)$, and neuropathic $(O)$ and non-neuropathic ( $\mathbf{E}$ ) Type 1 diabetic patients. All subjects followed a fixed eating pattern which included an overnight fast and light meals at $07.00,12.00$ (L) and 17.45 hours (D). Insulin was administered to diabetic patients at 07.00 and 18.00 hours. Values are cxpressed as mean \pm SEM

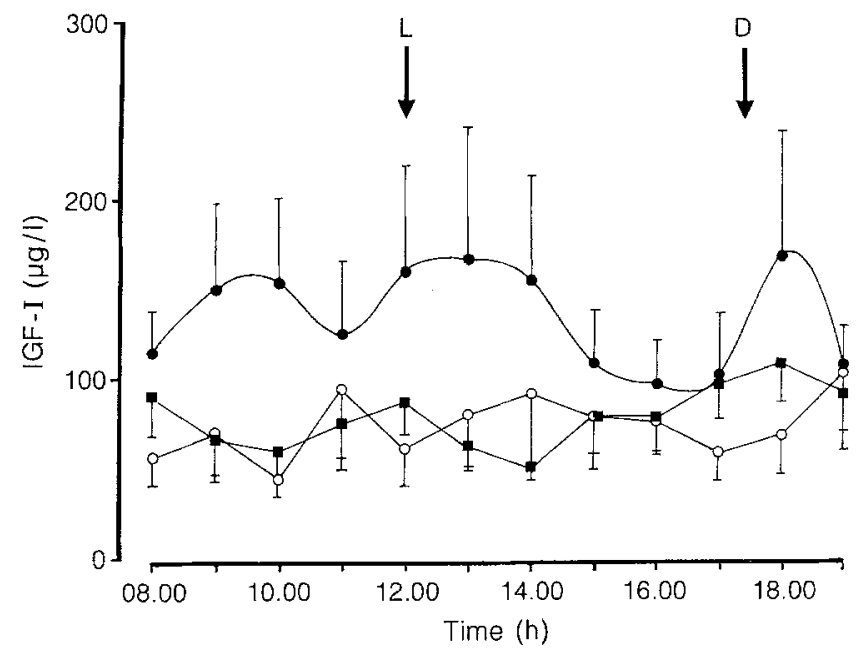

Fig. 2. Plasma insulin-like growth factor I (IGF-I) concentrations measured in normal subjects ( $)$, and Type 1 diabetic patients with peripheral neuropathy (O), and without neuropathy ( $\mathbf{0})$. All subjects followed a fixed eating pattern which included an overnight fast and light meals at $07.00,12.00$ (L) and 17.45 hours (D). Insulin was administered to diabetic patients at 07.00 and 18.00 hours. Values are expressed as mean \pm SEM

as tracer and human insulin (WHO 1st International reference preparation) as standard. Separation of bound and free radioligand was by charcoal separation. The assay had a detection limit of $1.0 \mathrm{mIU} / 1$, an inter-assay CV of less than $5 \%$ between $1-250 \mathrm{mIU} / 1$, and an intra-assay CV of less than $10 \%$ between $2-110 \mathrm{mIU} / \mathrm{l}$.

C-peptide measurement. Postprandial (13.00 hours) plasma C-peptide concentrations were measured by RIA (Serono Diagnostics, Woking, Surrey, UK).

\section{Statistical analysis}

Curves were plotted of IGF-I, IGFBP-1, glucose and insulin concentration against time and the area under each curve (AUC) was calculated as a summary statistic for each $11-h$ profile. The Mann-Whit- ney test for non-parametric data was used to compare AUC values between groups and the relationships between each factor were examined using Pearson correlation coefficients.

\section{Results}

The clinical details of the subjects included in this study are summarised in Table 1 which shows that there were no significant differences in the age range, or body mass index between any of the three subject groups. The duration of diabetes was similar between neuropathic and nonneuropathic patients.

There were marked differences between the groups in the 11-h plasma profiles of IGFBP-1 (Fig.1). In nondiabetic subjects the mean IGFBP-1 levels ranged from $0.86 \mu \mathrm{g} / \mathrm{l}$ to $1.99 \mu \mathrm{g} / \mathrm{l}$, and a rapid fall in plasma IGFBP-1 occurred after 13.00 hours to the lowest level at 15.00 hours (a decrease of $48 \%$ ) reflecting acute negative regulation of IGFBP-1 by insulin (which peaked at 13.00 hours following the midday meal). IGFBP-1 was much higher in the plasma of all of the diabetic patients (range, $11-40 \mu \mathrm{g} / \mathrm{l}$ for the neuropathic group, 2.3-15 $\mu \mathrm{g} / 1$ for the non-neuropathic group), and there was a clear diurnal variation, with the highest levels at 08.00 hours followed by a rapid fall during the morning. Comparison of the individual AUC values revealed that IGFBP-1 levels were significantly higher $(p=0.05)$ in the neuropathic group than in the non-neuropathic group.

Such differences were not reflected in plasma IGF-I levels (Fig. 2). In non-diabetic subjects IGF-I levels varied from $97 \mu \mathrm{g} / \mathrm{l}$ to $169 \mu \mathrm{g} / \mathrm{l}$ and there was no significant diurnal variation. Mean IGF-I levels in diabetic plasma were lower in both neuropathic (range, 44-104 $\mu \mathrm{g} / \mathrm{l}$ ) and nonneuropathic (range, $50-109 \mu \mathrm{g} / \mathrm{l}$ ) patients, but no significant difference was found between these two groups.

As expected, glucose was elevated in plasma from diabetic patients over the 11-h study period (Fig. 3) and comparison of 11-h AUC values (08.00-19.00 hours) revealed no significant difference between neuropathic and non-neuropathic diabetic patients. However, plasma glucose levels were clearly lower during the morning in the non-neuropathic group than the neuropathic group and comparison of AUC values between 08.00 and 13.00 hours revealed a highly significant difference between these groups ( $p=0.0006$ ).

Insulin levels in non-diabetic subjects (Fig.4) ranged between 6.2 and $26.4 \mathrm{mIU} / \mathrm{l}$, with a clear peak at 13.00 hours following the midday meal. In the Type 1 diabetic patients the mean plasma insulin levels (following injection at 07.00 hours) peaked at 09.00 hours (nonneuropathic) and 10.00 hours (neuropathic) after which there was a steady decline. Levels in both groups remained higher than those of non-diabetic subjects ( $p=0.033$ ) throughout the 11-h period (range, 12.8$24.4 \mathrm{mIU} / 1$ for neuropathic patients and $14.7-31 \mathrm{mIU} / \mathrm{l}$ in non-neuropathic patients) except at 13.00 hours. There was no difference in the insulin levels (AUC) between neuropathic and non-neuropathic patients. C-peptide was undetectable in plasma from all of the diabetic patients at 13.00 hours, indicating the absence of endogenous insulin.

In the 11-h profiles there were significant inverse correlations (AUC values) between IGFBP-1 and glucose 


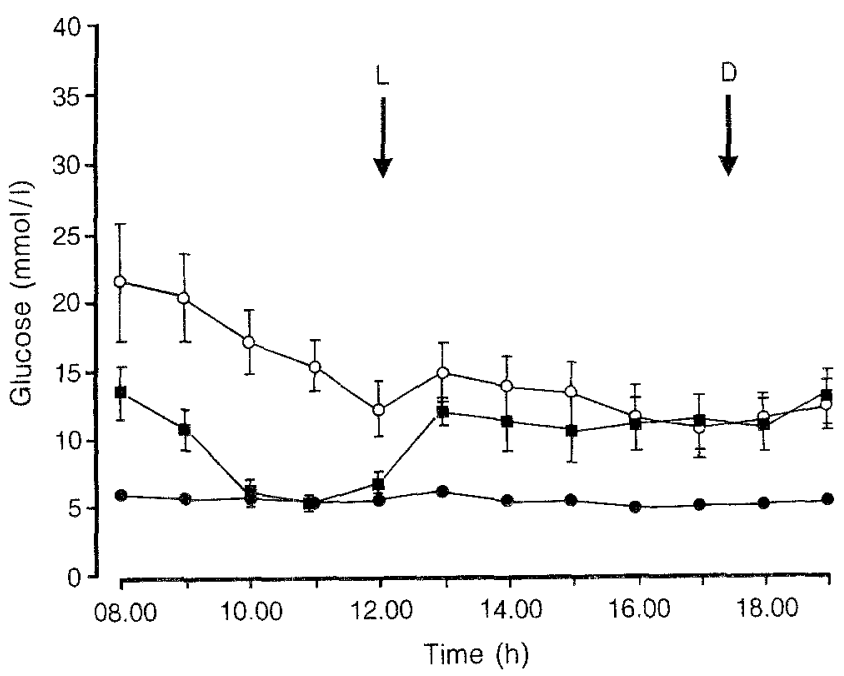

Fig. 3. Plasma glucose concentrations measured hourly for $11 \mathrm{~h}$ in eight non-diabetic subjects (-), eight neuropathic Type 1 diabetic patients $(O)$, and seven non-neuropathic diabetic patients ( $\mathbf{a})$. All subjects followed a fixed eating pattern which included an overnight fast and light meals at $07.00,12.00$ (L) and 17.45 hours (D). Insulin was administered to diabetic patients at 07.00 and 18.00 hours. Values are expressed as mean \pm SEM

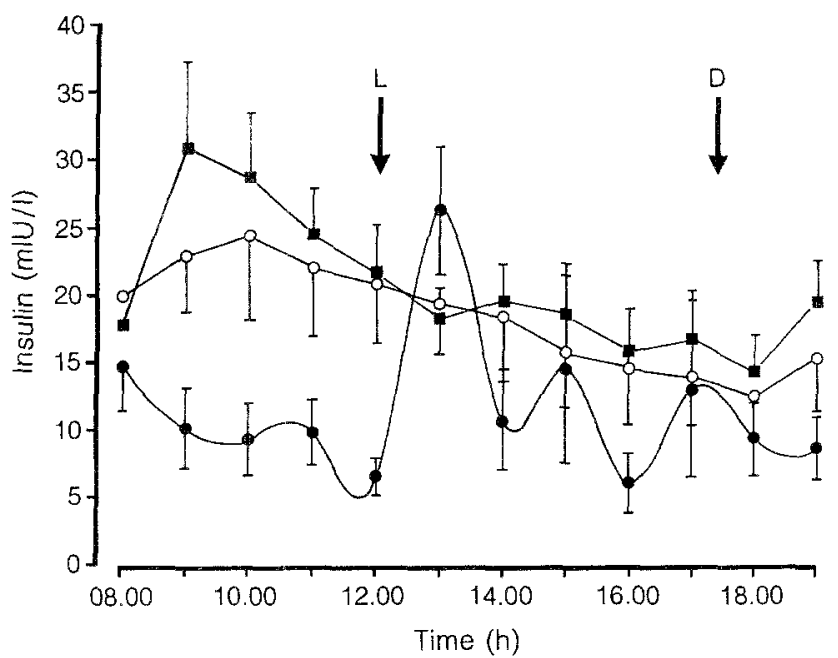

Fig.4. Plasma insulin concentrations measured in normal subjects $(\bullet)$, and Type 1 diabetic patients with peripheral neuropathy $(O)$, and without neuropathy ( $\mathbf{\square}$ ). All subjects followed a fixed eating pattern which included an overnight fast and light meals at 07.00, $12.00(\mathrm{~L})$ and 17.45 hours (D). Insulin was administered to diabetic patients at 07.00 and 18.00 hours. Values are expressed as mean \pm SEM

$(-0.88, p=0.01)$, IGFBP-1 and insulin $(-0.75, p=0.02)$ and IGFBP-1 and IGF-I $(-0.68, p=0.03)$ in non-diabetic subjects. A significant positive correlation $(0.89$, $p=0.001$ ) was found between IGF-I and insulin. In the diabetic patients there was a weak but significant positive correlation between $\mathrm{HbA}_{1}$ and IGFBP-1 (0.47, $\left.p=0.032\right)$. However, in both the non-neuropathic and the neuropathic diabetic groups the relationships between IGFBP-1 and glucose, insulin, and IGF-I were disrupted. Analysis of the 11-h AUC values for both diabetic groups revealed no significant positive correlation between IGF-I and insulin or negative correlations between IGFBP-1 and glucose. A significant negative correlation between IGFBP-1 and insulin $(-0.66, p=0.026)$ was retained in the neuropathic group but not in the non-neuropathic group.

\section{Discussion}

Our results show that there are clear abnormalities in the regulation and circulating levels of IGF-I and IGFBP-1 in Type 1 diabetes, and that there are changes, particularly in IGFBP-1 which are more pronounced in neuropathic as compared to non-neuropathic patients. In non-diabetic subjects insulin is negatively correlated with IGFBP-1 and positively correlated with IGF-I and our results are in agreement with those of other workers [17] who have investigated the relationship between insulin, IGF-I and IGFBP-1 in plasma. This is consistent with the concept that insulin is a major regulator of IGF-I and IGFBP-1 in plasma and that the anabolic effects of insulin are mediated through changes in IGF-I activity. The rapidity with which insulin regulates IGFBP-1 secretion has been demonstrated previously [9] and is reflected in the present study by the rapid fall in plasma IGFBP-1 within $3 \mathrm{~h}$ of a midday meal. These fluctuations appear to be superimposed on the diurnal variation of plasma IGFBP-1 (i.e. levels are higher early in the morning and fall progressively throughout the day) suggesting that factors other than insulin may also have a role in regulating IGFBP-1. Fluctuations of plasma cortisol for example are similar to those of IGFBP-1 and in view of the recent reports on glucocorticoid-stimulated IGFBP-1 secretion [18], it is possible that these diurnal rhythms are related. In contrast to IGFBP-1, we did not find that plasma IGF-I levels responded rapidly to changes in plasma insulin. The positive correlation (AUC values) between these two peptides may therefore be due to an effect of insulin level and activity on IGF-I secretion over prolonged periods of time.

In the non-neuropathic diabetic patients there was a gross elevation of plasma IGFBP-1 and a much more pronounced diurnal variation. A similar pattern has been reported by others [19], however, our study shows that this elevation of IGFBP-1 in diabetic patients occurred despite persistent hyperinsulinaemia. Plasma IGFBP-1 levels were therefore inappropriately high for the circulating insulin levels in comparison with non-diabetic control subjects. Plasma IGF-I levels were also reduced in non-neuropathic diabetic patients relative to non-diabetic control subjects, as were plasma IGF-II levels (data not shown). Taken together, these results suggest a lack of effect of insulin on hepatocytes (the major source of circulating IGF-I and IGFBP-1). This may simply reflect non-physiological insulin administration (i.e.the physiological regulation of IGFBP-1 and IGF-I is by pulses of pancreaticinsulin delivered through the hepatic portal vein) or may suggest a degree of resistance to insulin regulation, particularly the inhibitory effects of insulin on IGFBP-1 secretion. Irrespective of the mechanism, these abnormalities are sufficient to disrupt the normal relationships which exist between insulin, IGF-I, and IGFBP-1 in plasma.

In neuropathic diabetic patients, these abnormalities were even more pronounced and we found that the mean plasma IGFBP-1 levels at 08.00 hours were 2.7 times higher than in non-neuropathic patients. Given that these differences were not due to differences in insulin levels, 
the presence of anti-insulin antibodies (which were more prevalent in the non-neuropathic group, data not shown) or to residual endogenous insulin in the non-neuropathic group (i.e. postprandial C-peptide was undetectable in both groups), it seems likely that the neuropathic patients in our study were more resistant to the hepatic effects of insulin on IGFBP-1 secretion than non-neuropathic patients. The significantly higher morning glucose levels in these patients may mean that this is part of a more generalized resistance to the actions of insulin.

The consequences of elevated circulating IGFBP-1 levels are unknown, but one can speculate that they may be relevent to a number of diabetic complications involving abnormalities in cellular growth or regeneration. Several in vitro studies have shown that IGFBP-1 can inhibit the binding of IGF-I to its cell surface receptors and thereby inhibit IGF-I action [11]. Furthermore, IGFBP-1 levels in plasma from diabetic patients are also associated with IGFI inhibitory activity on cartilage sulphation [20]. Thus, current opinion favours an inhibitory role of IGFBP-1 on the action of IGF-I, although there have been reports that IGFBP-1 can enhance the mitogenic response of some cell types to IGF-I under certain conditions [21]. The relationship between circulating IGFBP-1 and local IGFBP-1 concentrations in neuronal tissue is unknown at present. In view of a recent report [22] that capillaries are permeable to IGFBP-1 and that insulin increases transcapillary permeability, it seems likely that tissue levels of IGFBP-1 will also be elevated in poorly-controlled diabetic patients, particularly those with hyperinsulinaemia.

Acknowledgements. The authors would like to thank the staff of Medix Biochemica (Kaunianen, Finland) for the kind gift of IGFBP-1 immunoenzymetric assay kits and Ciba-Geigy (Basle, Switzerland) for provision of rhIGF-I conjugated to human serum $\alpha$-globulin. This study was supported by grants from the North West Regional Health Authority, the British Diabetic Association, and Fidia Pharmaceuticals.

\section{References}

1. Young RJ, Macintyre CCA, Martyn CN et al. (1986) Progression of subclinical polyneuropathy in young patients with type 1 (insulin-dependent) diabetes: associations with glycaemic control and microangiopathy (microvascular complications). Diabetologia 29:156-161

2. Winegrad AI, Simmons DA, Martin DB (1983) Has one diabetic complication been explained? New Engl J Med 308: 152-154

3. Britland ST, Young RJ, Sharma AK, Clarke BF (1990) Association of painful and painless diabetic polyneuropathy with different patterns of nerve fiber degeneration and regeneration. Diabetes 39: 898 908

4. Hansson HA, Dahlin LB, Danielsen N et al. (1986) Evidence indicating trophic importance of IGF-I in regenerating peripheral nerves. Acta Physiol Scand 126: 609-614

5. Ekstrom PAR, Kanje M, Skottner A (1989) Nerve regeneration and serum levels of insulin-like growth factor-1 in rats with streptozotocin-induced insulin deficiency. Brain Res 496: 141-147

6. Griffen SC, Russell SM, Katz LS, Nicoll CS (1987) Insulin exerts metabolic and growth promoting effects by a direct action on the liver in vivo: clarification of the functional significance of the portal vascular link between the beta cells of the pancreatic islets and the liver. Proc Natl Acad Sci USA 84: 7300-7304

7. Sara VR, Hall K (1990) Insulin-like growth factors and their binding proteins. Physiol Rev 70: 591-614
8. Brinkman A, Groffen C, Kortleve DJ, Drop SLS (1988) Organization of the gene encoding the insulin-like growth factor binding protein IBP-1. Biochem Biophys Res Comm 157: 898-907

9. Suikkari AM, Koivisto VA, Rutanen EM, Jarvinen HY, Karonen SL, Seppala M (1988) Insulin regulates the serum levels of low molecular weight insulin-like growth factor binding protein. $\mathbf{J}$ Clin Endocrinol Metab 66: 266-272

10. Suikkari AM, Koivisto VA, Koistinen R, Seppala M, Yki-Jarvinen $H$ (1989) Dose response characteristics for suppression of low molecular weight plasma insulin-like growth factor binding protein by insulin. J Clin Endocrinol Metab 68: 135-140

11. Burch WM, Correa J, Shively JE, Powell DR (1990) The 25 kilodalton insulin-like growth factor (IGF) binding protein inhibits both basal and IGF-I mediated growth of chick embryo pelvic cartilage in vitro. J Clin Endocrinol Metab 70: 173-180

12. Holly JMP, Biddlecombe RA, Dunger DB et al. (1988) Circadian variation of $\mathrm{GH}$ independent IGF - binding protein in diabetes mellitus and its relationship to insulin. Clin Endocrinol (Oxf) 29: 667-675

13. Brismar K, Gutniak M, Povoa G, Werner S, Hall K (1988) Insulin regulates the $34 \mathrm{kDa}$ IGF binding protein in patients with diabetes mellitus. J Endocrinol Invest 11: 599-602

14. Young RJ, Zhou YQ, Rodriguez E, Prescott RJ, Ewing DJ, Clarke BF (1986) Variable relationship between peripheral somatic and autonomic neuropathy in patients with different syndromes of diabetic polyneuropathy. Diabetes 35: 192-197

15. Daughaday WH, Mariz IK, Blethen SL (1980) Inhibition of access of bound somatomedin to membrane receptor and immunobinding sites: a comparison of radioreceptor and radioimmunoassay of somatomedin in native and acid-ethanol extracted serum. J Clin Endocrinol Metab 51: 781-788

16. Gordon C, Yates AP, Davies D (1985) Evidence for a direct action of exogenous insulin on the pancreatic islets of diabetic mice: islet response to insulin pre-incubation. Diabetologia 28:291-294

17. Holly JMP, Cotterill AM, Jemmott RC et al. (1991) Inter-relations between growth hormone, insulin, insulin-like growth factor-1 (IGF-I), IGF-binding protein-1 (IGFBP-1) and sex hormone binding globulin in acromegaly. Clin Endocrinol (Oxf) 34: $275-280$

18. Luo J, Reid RE, Murphy LJ (1990) Dexamethasone increases hepatic insulin-like growth factor binding protein-1 (IGFBP-1) mRNA and serum IGFBP-1 concentrations in the rat. Endocrinology $127: 1456-1462$

19. Baxter RC, Cowell CT (1987) Diurnal rhythm of growth hormone independent binding protein for insulin-like growth factors in human plasma. J Clin Endocrinol Metab 65: 432-440

20. Taylor AM, Dunger DB, Preece MA et al. (1990) The growth hormone independent insulin-like growth factor-1 binding protein BP-28 is associated with serum insulin-like growth factor-1 inhibitory bioactivity in adolescent insulin dependent diabetics. Clin Endocrinol (Oxf) 32:229-239

21. Elgin RG, Busby WH, Clemmons DR (1987) An insulin-like growth factor binding protein enhances the biologic response to IGF-I. Proc Natl Acad Sci USA 84: 3313-3318

22. Bar RS, Boes M, Clemmons DR et al. (1990) Insulin differentially alters transcapillary movement of intravascular IGFBP-1, IGFBP-2 and endothelial cell IGF-binding proteins in the rat heart. Endocrinology 127: 497-499

Received: 25 February 1992

and in revised form: 15 May 1992

Dr. S. R. Crosby

Department of Medicine

University of Manchester

Hope Hospital.

Salford M6 8HD

UK 